\title{
Pengaruh Harga, Kualitas Pelayanan, dan Inovasi Desain Terhadap Loyalitas Pembelian Merk Minorfighters
}

\section{Effect of Price, Service Quality, and Design Innovation on Minorfighters Brand Loyalty}

\author{
Roymon Panjaitan* \\ Komputer Akuntansi / Sekolah Tinggi Elektronika dan Komputer Pat / Indonesia \\ *Coresponding Author : e-mail: roymon_panjaitan@yahoo.com
}

\begin{abstract}
Abstrak
Meningkatnya pertumbuhan produk retail di Indonesia, menyebabkan semakin tingginya pula tingkat persaingan bisnis ritel yang dihadapi produk-produk dalam negeri. Kegunaan penelitian ini adalah untuk mendeteksi pengaruh tingkat harga, kualitas layanan dan inovasi desain terhadap loyalitas pembelian yang ada pada merk Minorfighters. Peneliti mengambil sampel yang digunakan sebanyak 87 responden dengan metode purposive sampling. Pengumpulan data menggunakan kuesioner dan wawancara. Data diolah dengan menggunakan uji validitas, uji reliabilitas, analisis tabulasi silang, koefisien korelasi, koefisien determinasi, analisis regresi sederhana dan berganda, dan uji signifikansi. Hasil penelitian menunjukkan bahwa adanya faktor harga, kualitas pelayanan dan inovasi desain yang mempengaruhi secara positif terhadap loyalitas pembelian. Variabel inovasi desain memberikan pengaruh lebih besar terhadap loyalitas pembelian. Hasil ini sebagai hipotesis awal penulis yang dikaji dalam penulisan ini.
\end{abstract}

Kata Kunci: Harga, Kualitas layanan, Inovasi desain, dan Loyalitas pembelian.

\begin{abstract}
The increasing growth of retail products in Indonesia has led to the increasing level of competition in the retail business faced by domestic products. The usefulness of this research is to detect the influence of price levels, service quality and design innovation on purchase loyalty that exists in the Minorfighters brand. The researcher took a sample of 87 respondents using the purposive sampling method. Data collection using questionnaires and interviews. Data is processed using validity test, reliability test, cross tabulation analysis, correlation coefficient, coefficient of determination, simple and multiple regression analysis, and significance test. The results showed that the existence of price factors, service quality and design innovations that positively influence purchase loyalty. Design innovation variables have a greater influence on purchase loyalty. This result is the initial hypothesis of the authors examined in this paper.
\end{abstract}

Keywords : Price, Quality of service, Innovation design and Purchase loyalty. 
Jurnal Konsep Bisnis dan Manajemen, 5 (2) Mei 2019 Halaman : 186-195 


\section{PENDAHULUAN}

Pertumbuhan ekonomi di dalam bisnis produk retail, saat sekarang ini semakin bertumbuh pesat membuat para pengusaha mencari cara dan pasar yang tepat untuk memasarkan produknya (Ghanimata \& Kamal, 2012). Dinamika kehidupan yang terus berubah secara dinamis menghubungkan komunitas tertentu terhadap pembelian, penggunaan produk, ide atau pengalaman untuk meningkatkan kepercayaan diri dalam bersosialisasi yang akan menjadi kepuasan tersendiri. Para produsen mendapatkan celacela peluang usaha yang bervariasi, selain itu kebutuhan sosialita yang lebih memilih mengikuti trend menjadikan penyebab menjamurnya celah bisnis dengan berbagai macam produk pesaing. Dalam memilih suatu produk, masyarakat sudah berpikir selektif dan smart. Konsumen rela mengeluarkan biaya yang lebih besar guna memperoleh kepuasan secara lahiriah. Menurut Lembang (2010), meningkatnya persaingan mengharuskan pemasar untuk selalu mengembangkan dan menguasai market share.

Minorfighters Produk sebagai salah satu merk produk yang sudah terdaftar dan diakui keabsahan legalitasnya dari HAKI, adalah produk eceran untuk berbagai produk konsumtif lainnya. Oleh karena itu dengan latar belakang perkembangan ekonomi yang selalu maju secara dinamis, merupakan suatu tantangan dan ancaman bagi pemasok bisnis retail produk. Minorfighters Produk harus mampu bersaing dan merubah sistem pelayanan dan kualitasnya. Loyalitas konsumen sasaran uatama dalam strategi peningkatan kepuasan pemasaran yang sangat relevan (Oliver,2007:31).
Strategi pemasaran yang berfokus pada loyalitas konsumen harus mengerti karakteristik dan mengetahui kebutuhan konsumen. Pada hakikatnya, tujuan sebuah bisnis adalah menciptakan kepuasan para pelanggan (Schnaars dalam Tjiptono dan Chandra, 2004:199). Kepuasan atau ketidakpuasan konsumenn merupakan respon terhadap ketidaksesuaian antara harapan sebelumnya dan realitas dari sebuah produk. Atau dapat dijelaskan bahwa persoalan dalam memenuhi keinginan pelanggan masa akan datang dari gambaran masa lalu. Persaingan bisnis yang terus berkembang harus berkompetisi menciptakan produk melalui strategi yang kreatif, inovatif serta efisien, sehingga pelanggan banyak yang memilih produk unik yang pada akhirnya akan membentuk "loyalitas" (Javalgi dalam Ratih Hurriyati, 2005:127).

Dalam penelitian ini diketahui ada beberapa penyebab konsumen mau kembali dengan berulang. Pengeluaran yang terjangkau oleh pembeli dapat menjadi indikator pertimbangan dalam pembelian kembali. . Penetapan harga harus mengikuti tingkat perekonomian konsumen, agar harga sesuai oleh daya beli konsumen. Bagi produsen penetapan harga berguna untuk menghitung harga pokok produksi, memperoleh laba, pertumbuhan penjualan maksimum dan kepemimpinan kualitas produk, sedangkan bagi pemakai atau pengguna produk , harga menjadi pertimbangan dalam melakukan transaksi jual beli, karena harga mempengaruhi pola pikir dalam bertransaksi terhadap suatu produk. Menurut Walton (2004:17) harga dan kualitas memiliki dampak yang bisa 


\section{Roymon Panjaitan, Pengaruh Harga, Kualitas Pelayanan, dan Inovasi Desain Terhadap Loyalitas Pembelian Merk Minorfighters}

mempengaruhi terhadap keinginan pembelian kembali.

Kualitas pelayanan mempengaruhi tindakan dalam loyalitas pembelian produk secara langsung yang harus dipahami bagi produsen. Kualitas pelayanan menstimulus pelanggan untuk loyal untuk membeli kembali setiap produk baru diterbitkan dan dijual kepada masyarakat. Implikasinya akan mendorong pelanggan yang loyal untuk tetap berkomitmen pada produk pilihannya dan layanan yang mampu berkontribusi dalam peningkatan pembauran pemasaran secara luas. Kualitas pelayanan mampu menjaga hubungan bisnis dengan baik kepada konsumen. Pelayanan yang terbaik akan mengimplikasikan peningkatan la ba produsen. Keputusan produsen melakukan upaya perbaikan pelayanan yang sistematis merupakan fondasi yang menentukan dan meminimalkan komplain konsumen dari suatu kegagalan (Elu,2005).

Langkah strategis perusahaan dalam peningkatan mutu produk adalah dengan terus melakukan inovasi desain produk. Tujuan utama menjadi unggul dalam berkompetisi di pasar adalah dengan menciptakan inovasi, inovasi harus seiring berjalan dengan differentiation berbagai produk. Inovasi sangat berkaitan erat dan penunjang dalam pemilihan konsumen dalam keputusan pembelian yang akhirnya akan selalu mencari produk terbaru. Desain yang berbeda daripada yang lain antar produsen akan menjadi faktor pembanding dan menjadi nilai tambah bagi produk itu sendiri. Inovasi akan memberikan nilai yang berbeda dengan memberikan solusi yang terbaik akan keinginan (Masda, 2012). Inovasi desain yang terus melakukan perubahan akan meningkatkan kualitas dan keunggulan produk dalam persaingan bagi pelaku bisnis atau produsen yang akhirnya berdampak pula pada hasil kerja perusahaan (Hartini,2012).

Dari hasil penelitian yang telah dikemukakan oleh Made Caesar Surya Dwiputra (2017), menyatakan bahwa untuk mempertahankan kualitas produk sepeda motor Vespa harus selalu tetap berinovasi seiring perubahan jaman ke depannya dan tetap meningkatkan pelayanan terhadap konsumen dapat meminimalkan biaya yang bersaing untuk masyarakat menengah.

Berdasarkan hasil pengamatan diatas, peneliti juga terlibat langsung sebagai seorang produsen, pencipta ide desain serta pemasar produk yang menjual produknya ke masyarakat umum. Hal ini yang menjadi penulis berkeinginan melakukan penelitian tentang pengaruh harga, kualitas pelayanan, dan inovasi desain terhadap kepuasan konsumen (studi kasus merk Minorfighters Prod).

Berdasarkan latar belakang masalah, maka rangkuman masalah yang didapat sebagai berikut :

1. Bagaimana pengaruh harga terhadap loyalitas pembelian produk merk Minorfighters ?

2. Bagaimana dampak kualitas pelayanan terhadap loyalitas pembelian produk merk Minorfighters?

3. Bagaimana pengaruh inovasi desain terhadap loyalitas pembelian produk merk Minorfighters ?

4. Bagaimana hubungan harga, kualitas pelayanan dan inovasi desain secara bersama-sama terhadap loyalitas pembelian produk merk Minorfighters?

Berdasarkan rumusan masalah yang telah disebutkan di atas maka tujuan 
penelitian ini adalah :

1. Untuk mengetahui dan menganalisis signifikansi harga terhadap loyalitas pembelian produk merk Minorfighters.

2. Untuk mengetahui dan menganalisis pengaruh kualitas pelayanan terhadap loyalitas pembelian produk merk Minorfighters.

3. Untuk mengetahui dan menganalisis hubungan dampak inovasi desain terhadap loyalitas pembelian produk merk Minorfighters.

4. Untuk mengetahui dan menganalisis pengaruh harga, kualitas pelayanan dan inovasi desain secara bersama-sama terhadap loyalitas pembelian produk merk Minorfighters.

Secara sederhana, berikut kerangka pemikirannya :

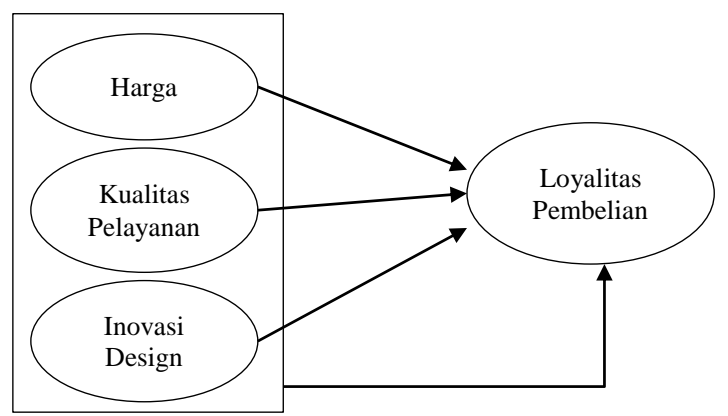

Gambar 1. Kerangka Berpikir Konseptual

\section{METODE PENELITIAN}

Pemilihan metode yang digunakan berdasarkan tujuan penelitian adalah asosiatif, yaitu penelitian yang menguji hubungan antara dua variabel atau lebih. Jenis data yang digunakan adalah data kuantitatif.

Berdasarkan hasil penelitian yaitu "Pengaruh harga, kualitas pelayanan dan Inovasi desain terhadap loyalitas pembelian (studi kasus merk Minorfighters Prod) ", maka jumlah variabel yang diteliti dapat dibedakan menjadi dua :

1. Variabel independen $X_{1}$ adalah harga, $X_{2}$ adalah kualitas pelayanan, $\mathrm{X}_{3}$ adalah inovasi desain

2. Variabel bebas (Y) adalah loyalitas pembelian

Dari pengertian tersebut, maka populasi dalam penulisan materi ini adalah pengguna produk merk Minorfighters. Metode pengambilan contoh dalam kajian penulisan ini dengan menggunakan purposive sampling atau judgement sampling (penentuan sampel dengan pertimbangan tertentu). Dengan jumlah responden 87 orang dan mengacu pada rule of thumb yang ditemukan oleh Roscoe (Supramono \& Haryanto, 2005) bahwa ukuran sampel yang dikatakan layak menjadi responden adalah berkisar lebih dari 30-500 orang.

Pengkajian sumber data, diperoleh dari data primer. Data utama dalam penelitian ini adalah jawaban responden melaui kuisioner yang telah diisi serta hasil data penjualan produk Minorfighters. Sumber sekunder dalam data ini melalui media elektronik lewat internet dan studistudi empiris saling terkait dengan variabel yang digunakan.

Metode yang disajikan dari analisis ini adalah untuk menunjukkan hubungan antara variabel dependen (Y) dengan variabel independen $(\mathrm{X})$ menggunakan persamaan regresi berganda yaitu :

$$
Y=a+b_{1} X_{1}+b_{2} X_{2}+b_{3} X_{3}+u i
$$

Keterangan

$\mathrm{Y} \quad=$ Variabel dependen yaitu loyalitas pembelian

$=$ Konstanta

= Variabel Independen yaitu harga 


\section{Roymon Panjaitan, Pengaruh Harga, Kualitas Pelayanan, dan Inovasi Desain Terhadap Loyalitas Pembelian Merk Minorfighters}

$\mathrm{X}_{2}=$ Variabel Independen yaitu kualitas pelayanan

$\mathrm{X}_{3} \quad=$ Variabel Independen yaitu inovasi desain

$\mathrm{b}_{1}, \mathrm{~b}_{2}, \mathrm{~b}_{3}=$ Koefisien Variabel $\mathrm{X}_{1}, \mathrm{X}_{2}, \mathrm{X}_{3}$

ui $=$ Faktor gangguan (gujarati, 1995:130)

\section{HASIL DAN PEMBAHASAN}

\section{Hasil Uji Asumsi Klasik}

Uji bertujuan untuk memastikan bahwa hasil telah berdistribusi normal. Uji yang dilakukan pada peneltian ini adalah uji normalitas, multikolinieritas, heteroskedastisitas dan autokorelasi. Hasil Uji Normalitas

Untuk melakukan analisa pengujian apakah distribusi data bersifat normal atau tidak, digunakan uji statistik non parametik Kolmogorov -Smimov (K-S) dan uji grafik pplot. Data yang terdistribusi normal ditunjukkan dengan nilai sig $>0.05$ atau 5\% untuk uji statistik dan titik-titik plot tersebar di sekitar garis diagonal untuk uji grafik p-plot. Hasil pengujian normalitas dapat digambarkan pada tabel dan gambar berikut:

\section{Gambar 1. Uji Kolmogorov Smirnov (K-S)}

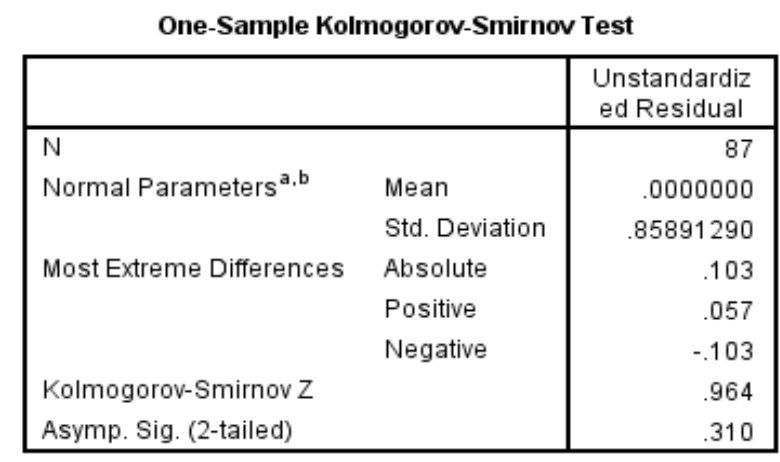

a. Test distribution is Normal.

b. Calculated from data.
Gambar 1 menunjukkan nilai Kolmogorv-Smirnov adalah 0.964 dengan probabilitas signifikansi 0.310 lebih besar $\alpha=$ 0.05 hal ini berarti hipotesis nol diterima dengan arti bahwa data residual terdistribusi normal dan data hasilnya telah memenuhi asumsi normalitas.

Kemudian, gambar berikut ini merupakan hasil uji normalitas dengan uji grafik $p$-plot dan histogram

\section{Gambar 2. Histogram}

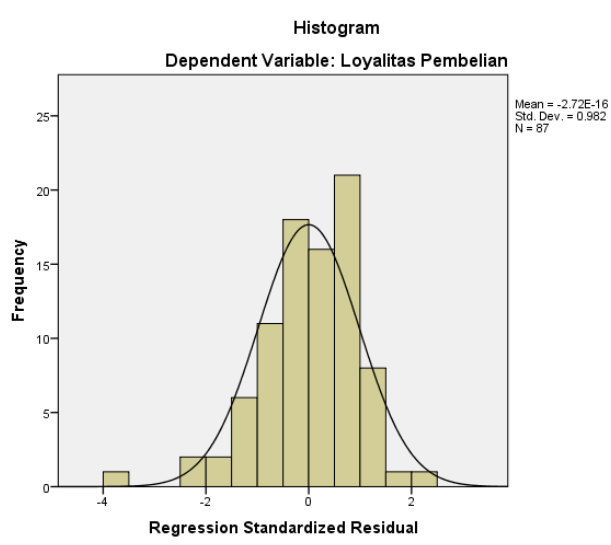

\section{Gambar 3. Grafik P-Plot}

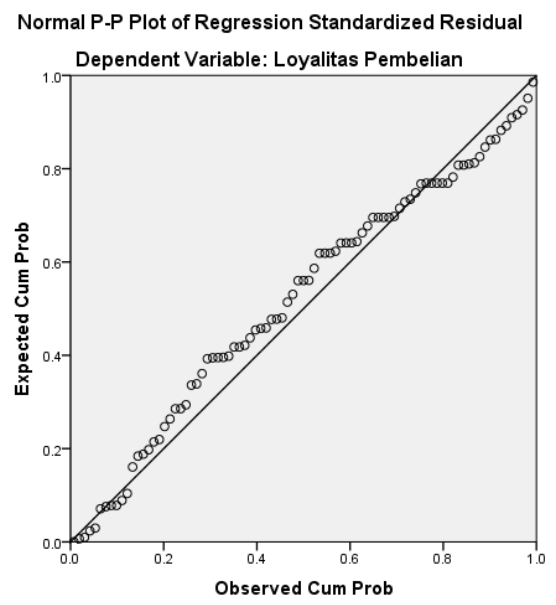

Gambar 3 dapat disimpulkan bahwa pola distribusi bersifat normal. Gambar 3 juga menunjukkan plot terlihat titik-titik yang menyebar di sekitar garis diagonal. Gambar 3 dapat ditarik kesimpulan bahwa kedua grafik 
tersebut menunjukkan bahwa model regresi memenuhi uji asumsi normalitas.

\section{Hasil Uji Multikolinearitas}

Uji multikolonieritas penelitian ini dilihat dari nilai tolerance $(\mathrm{T})$ dan variance inflation factor (VIF). Tabel 3 merupakan tabel hasil uji multikolonieritas, dari nilai tolerance menunjukkan tidak ada variabel berdiri sendiri yang memiliki nilai batas tolerance kurang dari 0.10. Variance inflation factor menunjukkan bahwa tidak ditemukan satu variabel independen yang memiliki nilai VIF > 10.0 sehingga dapat diberikan pendapat bahwa tidak ditemukan adanya korelasi yang berpengaruh antar variabel independen.

\section{Coefficients $^{\mathrm{a}}$}

\begin{tabular}{|ll|r|r|}
\hline \multirow{2}{*}{ Model } & \multicolumn{2}{|c|}{ Collinearity Statistics } \\
\cline { 3 - 4 } & & Tolerance & \multicolumn{1}{c|}{ VIF } \\
\hline 1 & Harga & .584 & 1.711 \\
& Kualitas Pelayanan & .829 & 1.206 \\
& Inovasi Design & .567 & 1.763 \\
\hline
\end{tabular}

a. Dependent Variable: Loyalitas Pembelian

\section{Hasil Uji Heteroskedastisitas}

Hasil uji heterokedastisitas menggunakan grafik scatterplot dengan melihat nilai prediksi variabel dependen yaitu ZPRED dengan residualnya SRESID.

\section{Gambar 5. Grafik Scatterplot}

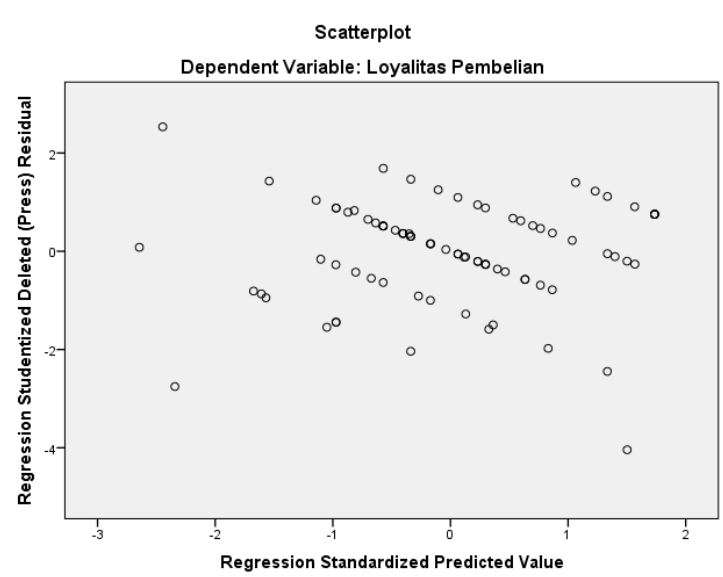

Dari Gambar 4.3 menunjukkan plots atau titik- titik menyebar secara acak baik di atas maupun di bawah angka 0 pada sumbu Y, sehingga model regresi ini layak dipakai untuk memprediksi loyalitas pelanggan berdasarkan variabel-variabel yang mempengaruhinya yaitu harga, kualitas pelayanan dan inovasi design.

\section{Hasil Uji Autokorelasi}

Pengujian ini merupakan model regresi linier untuk menguji hubungan antara kesalahan penganggu pada periode saat ini dengan kesalahan penggangu pada periode sebelumnya. Uji yang dipergunakan untuk mengetahui korelasi otomatis dalam penelitian ini adalah dengan uji DurbinWatson (DW test), dengan kriteria dibawah ini :

a. Terjadi autokorelasi jika nilai DW < dari $\mathrm{dL}$ atau > dari (4-dL).

b. Tidak terjadi autokorelasi, jika berada diantara dU dan (4-dU).

c. Tidak memberikan hasil yang pasti, jika nilai DW terletak antara dL dan dU atau di antara (4-dL) dan (4-dU).

Di bawah ini adalah analisa tabel dari penjelasan di atas :

\section{Hasil Uji Autokorelasi DW-Test}

\section{Model Summary ${ }^{\text {b }}$}

\begin{tabular}{|c|c|}
\hline Model & Durbin-Watson \\
\hline 1 & $2.085^{a}$ \\
\hline \multicolumn{2}{|c|}{$\begin{array}{l}\text { a. Predictors: } \\
\text { (Constant), Inovasi } \\
\text { Design, Kualitas } \\
\text { Pelayanan, Harga }\end{array}$} \\
\hline \multicolumn{2}{|c|}{$\begin{array}{l}\text { b. Dependent } \\
\text { Variable: Loyalitas } \\
\text { Pembelian }\end{array}$} \\
\hline
\end{tabular}

Dari hasil uji autokorelasi, diperoleh nilai Durbin-Watson (D-W) yaitu sebesar 2.085. Sementara itu dengan $\mathrm{K}=3$ dan $\mathrm{N}=87$ 


\section{Roymon Panjaitan, Pengaruh Harga, Kualitas Pelayanan, dan Inovasi Desain Terhadap Loyalitas Pembelian Merk Minorfighters}

diperoleh nilai dU sebesar 1.7232 dan nilai dL sebesar 1.5808. Nilai Durbin-Watson (D-W) = 2.085 terletak di antara berada di antara nilai $\mathrm{dU}$ dan $4-\mathrm{dU}=4-1.7232=2.768>2.085<$ 2.768. Berdasarkan hasil penghitungan ini, berarti pada uji autokorelasi tersebut terdapat masalah autokorelasi.

\section{Uji Analisis Regresi Berganda}

Uji yang bertujuan untuk memperkirakan keadaan variabel bebas (kriterum) bila lebih dari satu atau lebih variabel tidak bebas sebagai faktor prediktor. Pada penelitian ini, loyalitas pelanggan ditetapkan sebagai variabel dependen, sedangkan variabel independen adalah harga, kualitas pelayanan dan inovasi design. Berikut hasilnya yang dilakukan dengan SPSS.

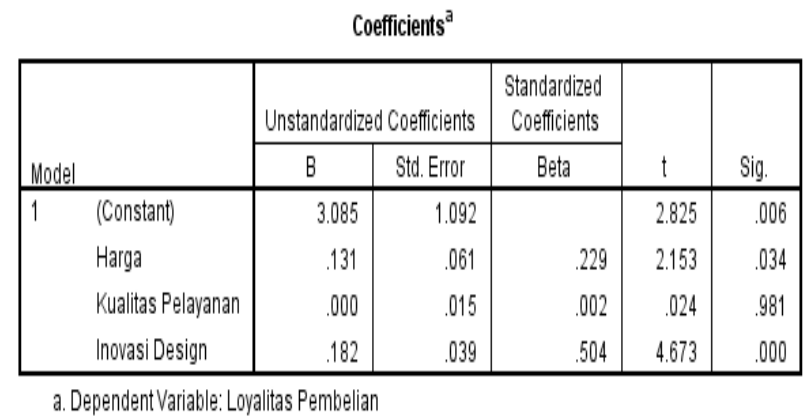

Sumber : Hasil Olah Data SPSS Versi 21.0

Berdasarkan hasil analisa yang telah dilakukan, maka diperoleh model regresi linier berganda sebagai berikut :

\section{$Y=3.085+0.131 X_{1}+0.000 X_{2}+0.182 X_{3}+e$}

Persamaan regresi linier berganda di atas dapat dijelaskan bahwa :

1. Nilai konstanta sebesar 3.085 artinya apabila semua variabel independen yaitu harga, kualitas pelayanan dan inovasi design dianggap konstan (bernilai 0), maka variabel dependen yaitu loyalitas pelanggan yang terjadi sebesar 3.085.

2. Koefisien regresi harga diperoleh nilai sebesar 0.131 bernilai positif yang berarti berkontribusi secara positif sehingga apabila terjadi peningkatan harga sebesar 1 satuan maka loyalitas pelanggan akan meningkat sebesar sebesar 0.131 .

3. Koefisien regresi kualitas pelayanan diperoleh sebesar 0.000 bernilai positif yang berarti menghasilkan dampak positif sehingga apabila terjadi peningkatan kualitas pelayanan sebesar 1 satuan maka kesetiaan pelanggan akan berkontribusi sebesar 0.000 .

4. Koefisien regresi inovasi design diperoleh sebesar 0.182 bernilai positif yang berarti memiliki signifikansi positif sehingga apabila terjadi perubahan inovasi design sebesar 1 satuan maka akan meningkatkan loyalitas pelanggan sebesar 0.182 .

Uji Hipotesis

Uji t

Uji yang dilakukan untuk menguji bagaimana ketergantungan masingmasing variabel harga, kualitas pelayanan dan inovasi design secara sendiri-sendiri terhadap loyalitas pembelian. Pengujian ini perbandingan thitung dengan tabel atau dengan melihat nilai signifikan $p$-value lebih kecil dari nilai alpha $=0.05(5 \%)$.

Berdasarkan hasil perhitungan, maka didapat informasi berikut:

a. Hipotesis $\mathbf{1}$ : harga dipengaruhi secara positif terhadap loyalitas pembelian.

Berdasarkan hasil pengujian hipotesis parsial (uji t) diperoleh nilai thitung pada variabel harga sebesar 2.153 dengan nilai signifikansi sebesar $0.034<$ dari $\alpha$ $=0.05$. Dengan hasi penghitungan data 
statistik di atas dapat dikatakan bahwa terdapat pengaruh yang positif atau dapat diterima antara harga terhadap loyalitas pembelian, sehingga hipotesis 1 diterima.

b. Hipotesis $\mathbf{2}$ : kualitas pelayanan berpengaruh signifikan terhadap loyalitas pembelian.

Berdasarkan hasil pengujian hipotesis parsial (uji t) diperoleh nilai thitung pada variabel kualitas pelayanan sebesar 0.024 dengan nilai signifikansi sebesar $0.981>$ dari $\alpha=0.05$. Dari hasil uji data ini maka diperoleh kualitas pelayanan tidak memberikan dampak terhadap loyalitas pembelian, sehingga hipotesis 2 ditolak.

c. Hipotesis 3 : invovasi design berpengaruh signifikan terhadap loyalitas pembelian.

Dari hasil statistik hipotesis parsial (uji t) diperoleh nilai thitung pada variabel inovasi desain sebesar 2.153 dengan nilai signifikansi sebesar $0.034<$ dari $\alpha$ $=0.05$. Dari hasil tersebut diasumsikan bahwa terdapat hasil yang berpengaruh antara inovasi design terhadap loyalitas pembelian, sehingga hipotesis 3 diterima.

Uji F

Pengujian ini dihitung untuk mendeteksi dugaan sementara secara simultan guna menunjukkan keterkaitan antara variabel-variabel independen secara bersama terhadap variabel dependen, yaitu dengan melakukan perbandingan $F_{\text {hitung }}$ dengan $F_{\text {tabel }}$ atau dengan melihat nilai signifikan $p$-value $<$ dari nilai alpha $=0.05$ (5\%).

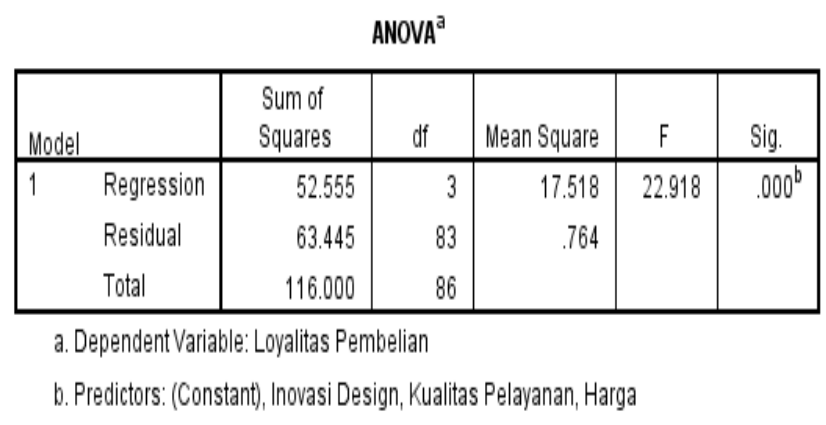

Berdasarkan data di atas diperoleh $\mathrm{F}_{\text {hitung }}$ sebesar 22.918 dengan nilai signifikansi sebesar 0.000. Nilai signifikansi yang diperoleh lebih kecil dari $\alpha=0.05(0.000<$ 0.05 ) sehingga dapat disimpulkan bahwa harga, kualitas pelayanan dan inovasi design secara simultan berpengaruh signifikan terhadap loyalitas pembelian.

\section{Analisis Koefisien Determinasi $\left(R^{2}\right)$}

Pengujian analisa ini berguna untuk mengukur seberapa akuratnya garis regresi taksiran dengan kenyataannya. Dalam hal ini, bertujuan mengukur seberapa besar loyalitas pelanggan dipengaruhi oleh harga, kualitas pelayanan dan inovasi design. Berikut hasil analisis data dengan menggunakan SPSS :

\section{Model Summary}

\begin{tabular}{l|l|l|c|c|}
\hline Model & R & R Square & $\begin{array}{c}\text { Adjusted R } \\
\text { Square }\end{array}$ & $\begin{array}{c}\text { Std. Error of } \\
\text { the Estimate }\end{array}$ \\
\hline 1 & $.673^{\mathrm{a}}$ & .453 & .433 & .874 \\
\hline
\end{tabular}

Berdasarkan hasil pengujian yang dilakukan, $\mathrm{R}^{2}$ sebesar 0.453 , atau $45.3 \%$. Hal ini menunjukkan $45.3 \%$ loyalitas pembelian merk Minorfighters Prod di pengaruhi oleh variabel yang tidak saling berkaitan yaitu harga, kualitas pelayanan dan inovasi design. Sedangkan 54.7\% sisanya dipengaruhi oleh variabel yang 


\section{Roymon Panjaitan, Pengaruh Harga, Kualitas Pelayanan, dan Inovasi Desain Terhadap Loyalitas Pembelian Merk Minorfighters}

lain di luar variabel independen yang dibahas dalam penelitian lain.

\section{SIMPULAN}

1. Faktor harga memberikan kontribusi secara positif terhadap peningkatan loyalitas pembelian merek Minorfighters Prod.

2. Kualitas pelayanan tidak memberikan dampak secara lurus terhadap loyalitas pembelian merek Minorfighters Prod.

3. Inovasi design berkontribusi terhadap loyalitas pembelian merek Minorfighters Prod.

4. Harga, kualitas pelayanan dan inovasi design secara simultan memberikan dampak yang positif terhadap loyalitas pembelian merek Minorfighters Prod.

\section{UCAPAN TERIMA KASIH}

Puji dan syukur kepada Tuhan Yang Maha Esa dan seluruh pihak Keluarga besar Minorfighters Produk khususnya Bapak Agus Djanuar sebagai pemilik merk Minorfighters, yang telah memberikan ijin serta seluruh konsumen yang terlibat dalam wawancara atau kuisioner dalam penelitian ini. Harapan penulis hasil penelitian ini, dapat memberikan tanggapan positif terhadap produsen merk Minorfighters prod untuk meningkatkan karya terbaik dan bersinergi dalam menghadapi revolusi pasar yang terus memperbaharui inovasi kreatinya. Bagi peneliti selanjutnya, penulis berharap dapat menambahkan faktor lain yang dapat mempengaruhi kualitas produk Merk Minorfighters bagi konsumen.

\section{DAFTAR PUSTAKA}

Benson, R. J., Bugnitz, T., \& Walton, W. B. (2004). From Business Strategy to IT Action. USA: John Wiley and Sons, Inc.

Dua Lembang, Rosvita. (2010). Analisis Pengaruh Kualitas Produk, Harga, Promosi, dan Cuaua terhadap Keputusan Pembelian Teh siap Minum dalam Kemasan Merek Teh Botol Sosro. Fakultas Ekonomi Universitas Diponegoro Semarang

Elu, Balthasar (2005). Manajemen Penanganan Komplain Konsumen di Industri Jasa. Jurnal Ilmu Administrasi dan Organisasi, Bisnis\&Birokrasi, Vol. 13, No. 3 (September)

Ghanimata, Fiftyanita dan Kamal, Mustafa. (2012). Analisis Pengaruh Harga, Kualitas Produk, dan Lokasi Terhadap Keputusan Pembelian. Diponegoro Journal of Management. Volume 1, Nomor 2, Tahun 2012

Gunawan, Barbara \& Halim, Mazda. (2012). Pengaruh Ownership Retntion, reputasi auditor, Laba Perusahaan dan Underprising terhadap Nilai Perusahaan Dengan Kepemilikan Manajerial dan Institusional Sebagai Variabel Pemoderasi. Jurnal Akuntansi dan Investasi (2) : 99-115.

Hurriyati, Ratih (2005), Bauran Pemasaran dan Loyalitas Konsumen, Bandung Alfabeta

Oliver, 2007. Measurement and Evaluation of Satisfaction Processes in Retail Settings. Journal of Retailing. 57(3), 25-48

Made Caesar Surya Dwi Putra dan Ni Wayan Ekawati, (2017), Pengaruh Inovasi Produk, Harga, Citra Merek Dan Kualitas Pelayanan Terhadap Loyalitas Pelanggan Sepeda Motor Vespa. EJurnal Manajemen Unud, Vol. 6, No. 3, 2017: 1674-1700.

Sri hartini (2012). Peran Inovasi: Pengembangan Kualitas Produk dan Kinerja Bisnis. Jurnal Manajemen Dan Kewirausahaan, Vol.14, No. 1, Maret 2012: 63-90

Supramono \& Haryanto, Jony Oktavian. (2005). Desain Proposal Penelitian Studi Pemasaran. Yogyakarta : Andi

Tjiptono, Fandy dan Chandra, Gregorius, (2004), 
Jurnal Konsep Bisnis dan Manajemen, 5 (2) Mei 2019 Halaman : 186-195

Service, Quality Satisfaction. Penerbit Andi, Yogyakarta. 